\title{
EFFECT OF CHEMICAL AND ORGANIC FERTILIZER ON THREE VARIETIES OF BROAD BEAN
}

\author{
Walled B. AL-Deen Al-Leela Hussein J. M. AL-Bayati Fadel F. Rejab \\ Shamil Y. Hasan
}

Department of Horticulture and Land scap Design - College of Agriculture and

Forestry - University of Mosul - Iraq

E-mail: al bayati1956@yahoo.com

\begin{abstract}
The study was carried out in the field of vegetables Department of Horticulture and Land scap Design / Faculty of Agriculture and Forestry / University of Mosul / Iraq during the growth season 2017-2018 to study effect of two factors: the first three varieties of the broad been (Local, Turkish and French), the second three factors of the fertilizer is chemical fertilizer, and organic fertilizer with Atalopolina $\left(400 \mathrm{~kg} . \mathrm{ha}^{-1}\right)$ and a mixture of organic and chemical fertilizers (1/2 chemical fertilizer $+200 \mathrm{~kg}$. ha ${ }^{-1}$ of Atalopolina fertilizer) and control treatment (without fertilization). Implemented in the field using Split Plot Design within RCBD with three replication. The treatment of varieties was laid in the main plots and the fertilizers in the sub plots. The most important results can be summarized as follows: There was a significant difference between varieties, where the local variety significantly increased the plant height, Local and French varieties increased leaf area per plant and total yield of pods, the Turkish variety were significantly increased the seed weight per pod. As well as the chemical and organic fertilizers significantly increased number of branches per plant, biological yield, seeds weight per pod and total yield of pods, but chemical fertilizer significantly increased leaf area per plant, pod length and total yield of pods, chemical and control treatments increased average of pod weight. The results of interaction between factors showed that the local variety with chemical treatment significantly increased plant height, leaf area per plant, biological yield, yield of green seeds $5.91 \mathrm{t}^{\mathrm{h}} \mathrm{ha}^{-1}$ and total yield of pods $10.79 \mathrm{t}^{\mathrm{ha}} \mathrm{h}^{-1}$, but interaction between Turkish variety and control treatment significantly increased number of branches per plant and average of pod weight, the French variety with mixed the fertilizers increased dry matter of vegetative growth, and Turkish variety with mixed fertilizers increased number of pods per plant and seeds weight per pod, the French variety with chemical fertilizer increased pod length.
\end{abstract}

Key words: Organic, Chemical, fertilizer, Vicia faba L., Varieties. Received:24/4/2019, Accepted: 30/6/2019

\section{INTRODUCTION}

The broad been (Vicia faba L.) is one of important winter vegetables crops which belonging to Fabaceae family, which was known by humans, which has a high content of protein in the seeds about 25-30\% (Sabh et, al. 2008) and contains its seeds on carbohydrates up to $56 \%$ with the presence of mineral elements and fiber up to $6 \%$ and fat $1.5 \%$ (Kandil and Hala, 2007). It is of great importance to improve soil fertility by stabilizing atmospheric nitrogen through the root nodes in 
the soil in co-existence with the rhizobium bacteria, therefore, it is introduced in agricultural courses in order to improve the soil conditions and improve its properties and granular composition (Kandil and Erskine, 2001). The selection of the appropriate category within the production area is one of the main factors for the increase of the crop and the crop species. Ibrahem (2011) found that Spanish variety of broad bean a significantly increased number of pods per plant, number of seeds per pod, average of seed weight and total yield of pods compared to Local variety. Kakahy et, al. (2012) found that the Spanish variety of broad bean increased a significant the number of seeds per pod compared to Turkish and Local varieties. Dhary and AL-Baldawi (2017) observed that the Spanish variety of broad bean gave highest number of branches per plant, leaf area per plant, number of pods per plant, number of seeds per pod and green seed yield compared to Netherland and Local varieties.

The growth and productivity of the broad been is affected by many factors, including chemical and organic fertilizers, where N P K fertilizer is necessary to increase production. Plant nutrition is the most important factors affecting growth and yield. Phosphorus is an essential nutrient needed for plant because it plays an important role in many metabolic processes of the plant, as well as its role in improving the quality of the fruit (Ramadan and Adam, 2007). Phosphorus may be a critical constraint of legumes (Tsvetkova and Georgiev, 2007) as well as its advantage in creating deeper and more abundant roots (Sharma, 2002). Therefore, the use of organic fertilizer as a substitute for the chemical fertilizers in the role of this fertilizer in improving the soil structure and increase the efficiency of the roots on the absorption of water and soluble food from the soil and increase the ability of soil to retain water and nutrients and stimulate the activity of microorganisms in the soil and thus improve plant growth and their quality (Nuaimi, 2011). Farhan (2012) found that adding chicken manure to broad bean plants a significantly increased plant higher, branches number per plant, plant dry weight and total yield of pods. Jassim and AL-Dulaimi (2012) found that chicken and Cattle manure were superior in increasing plant height, branches number per plant, leaf area per plant, pods number per plant, pod weight and yield of green pods of broad bean plants. Jaseim et, al. (2015) found that adding chemical fertilizer $200 \mathrm{~kg}$. ha ${ }^{-1}$ N-P-K (18-18-18) and organic fertilizer (Sheep waste ) 10 t.ha $^{-1}$ led to a significant increasing the number of pods per plant, average of pod length and green seeds yield compared to control treatment. Kamal et, al.(2016) found that the use of organic manure (poultry waste decomposed) led to a significant increase in plant height, dry weight and the total yield of board been plants. Dhary and AL-Baldawi (2017) observed that organic manure preparation from weed plants caused a significantly effect on studied characters, which gave higher rate of yield and there were no significant differences between chemical fertilizer (NPK) at green seed yield, application of NPK showed highest number of branches per plant, leaf area, pods number per plant and seeds number per pod compared to control treatment. 


\section{MATERIALS AND METHODS}

The experiment was carried out in the vegetable field of the Department of Horticulture and Land scap Design/Faculty of Agriculture and Forestry / University of Mosul / Iraq during the growth season 2017- 2018 to study the effect of some factors in the growth and yield of broad been plant, the experiment consisted of two factors, the first factor being three varieties of broad been (local, Turkish and French) under the influence of three fertilizers treatments: the use of organic compost (Atalpollina), which contains the major elements and some micronutrients and organic matter, containing total nitrogen (N)Phosphorus (P2O5), potassium oxide (K2O) and water soluble magnesium (Mgo) concentration of 4\%, 4\%, 4\% and $0.5 \%$ for each nutrient respectively. This fertilizer also contains micronutrients such as $0.8 \%$ water-soluble iron and boron water-soluble is $0.2 \%$ in addition to the richness of this compost organic materials, which are: (organic carbon and biological and acidic and acidic Folic and amino acids) and chemical fertilizer (Urea) $46 \%$ and a mixture of organic fertilizer and chemical equal to the treatment of comparison. Before beginning of the experiment random soil samples from 0-30 $\mathrm{cm}$ were obtained and analyzed at the Department of Horticulture to determine soil physical and chemical properties (Table1).

Table (1):Physical and chemical properties of soil.

\begin{tabular}{|c|c|c|c|c|c|c|c|c|}
\hline $\begin{array}{c}\text { Sand } \\
\text { g. } \mathrm{kg}^{-1}\end{array}$ & $\begin{array}{c}\text { Loam } \\
\text { g. } \mathrm{kg}^{-1}\end{array}$ & $\begin{array}{c}\text { Clay } \\
\text { g. } \mathrm{kg}^{-1}\end{array}$ & $\begin{array}{c}\mathrm{N} \\
\mathrm{mg} \cdot \mathrm{kg}^{-1}\end{array}$ & $\begin{array}{c}\mathrm{P} \\
\mathrm{mg} \cdot \mathrm{kg}^{-1}\end{array}$ & $\begin{array}{c}\mathrm{K} \\
\mathrm{mg} \cdot \mathrm{kg}^{-1}\end{array}$ & $\begin{array}{c}\text { O.M } \\
\mathrm{mg} \cdot \mathrm{kg}^{-1}\end{array}$ & $\mathrm{pH}$ & $\begin{array}{c}\mathrm{EC} \\
\mathrm{dsm}^{-1}\end{array}$ \\
\hline 648.1 & 229.8 & 122.1 & 24.20 & 15.81 & 126.65 & 19.33 & 7.8 & 0.744 \\
\hline
\end{tabular}

The soil sample was analyzed in the Soil and Water Resources Department Laboratories / College of Agriculture and Forestry/ Mosul University.

The soil was divided in the form of farrows the distance between them $75 \mathrm{~cm}$ and the seeds were planted in 3/11/2018 on one sides of the farrows alternately the distance between the plant and the other $25 \mathrm{~cm}$, the number of plants in each experiment unit 16 plants, two farrows in each experimental unit $\left(3 \mathrm{~m}^{2}\right)$ the agriculture process was carried out after a week of planting to reduce the lack of germination of some seeds. Spray irrigation method was used in this experiment. The experiment was design in the Randomized Complete Block Design (RCBD) with three replicates. The treatment of varieties was laid in the main plots and the fertilizers treatments in the sub plots.

Parameters studied: - 1- Plant height $(\mathrm{cm})$. 2- Number of branches per plant. 3Leaf area $\left(\mathrm{dcm}^{2}\right.$. plant $\left.{ }^{-1}\right)$. 4- Dry matter percentage of vegetative growth. 5- Pod length $(\mathrm{cm}) .6$ - Biological yield $(\mathrm{gm}) .7$ - Number of pods per plant. 8- Average of pod weight $(\mathrm{gm})$. 9- Seeds weight $\left(\mathrm{gm}^{\mathrm{p}} \mathrm{pod}^{-1}\right)$. 10- Yield of green seeds $\left(\mathrm{t} . \mathrm{ha}^{-1}\right)$. 11Total yield of pods $\left(\mathrm{t}_{\mathrm{h}} \mathrm{a}^{-1}\right)$.

The results were statistically analyzed according to the design used by the SAS program (2001). The averages were compared using the Duncan's multiple range of 5\% (Al-Rawi and Khalaf Allah, 2000). 


\section{RESULTS AND DISCUSSION}

The results of table (2) showed that the Local variety a significantly increased plant height with other varieties, and leaf area with Turkish gave the best values $68.08 \mathrm{~cm}, 155.30 \mathrm{dcm}^{2}$. plant ${ }^{-1}$ respectively. While no significant observed between varieties with other charactestics.

The fertilizers effect showed that chemical fertilizer a significantly increased number of branches per plant 4.61 compared with control, and in leaf area and pod length $164.43 \mathrm{dcm}^{2}$. plant ${ }^{-1} 20.22 \mathrm{~cm}$ respectively compared with other treatments, while there is no significant between fertilizers in plant height and dry matter percentage of hill.

Table (3) showed that the interaction between Local variety and chemical fertilizer a significantly increased plant height, leaf area and dry matter percentage of hill $71.00 \mathrm{~cm}, 211.80 \mathrm{dcm}^{2}$. plant ${ }^{-1}$ and $21.09 \%$ respectively compared with other treatments, while Turkish variety with control treatment a significantly increased number of branches per plant 5.01, but French variety with chemical treatment a significantly increased the pod length $22.33 \mathrm{~cm}$ compared with other treatments.

Table (2): Effect of varieties and different fertilizer treatment levels of organic and chemical fertilizers on vegetative trials of broad been.

\begin{tabular}{|c|c|c|c|c|c|}
\hline Varieties & $\begin{array}{c}\text { Plant } \\
\text { height } \\
(\mathrm{cm})\end{array}$ & $\begin{array}{c}\text { Nu. of } \\
\text { branches per } \\
\text { plant }\end{array}$ & $\begin{array}{c}\text { Leaf area } \\
\left(\mathrm{dcm}^{2} . \text { Plant }^{-1}\right)\end{array}$ & $\begin{array}{c}\text { Dry } \\
\text { matter of } \\
\text { hill \% }\end{array}$ & $\begin{array}{c}\text { Pod length } \\
(\mathrm{cm})\end{array}$ \\
\hline French & $65.25 \mathrm{~b}$ & $4.41 \mathrm{a}$ & $152.15 \mathrm{a}$ & $20.11 \mathrm{a}$ & $19.25 \mathrm{a}$ \\
\hline Turkish & $63.83 \mathrm{~b}$ & $4.33 \mathrm{a}$ & $114.98 \mathrm{~b}$ & $17.00 \mathrm{a}$ & $17.78 \mathrm{a}$ \\
\hline Local & $68.08 \mathrm{a}$ & $4.33 \mathrm{a}$ & $155.30 \mathrm{a}$ & $19.00 \mathrm{a}$ & $19.16 \mathrm{a}$ \\
\hline
\end{tabular}

Fertilizers:

\begin{tabular}{|c|c|c|c|c|c|}
\hline Control & $65.44 \mathrm{a}$ & $4.22 \mathrm{~b}$ & $132.29 \mathrm{~b}$ & $18.75 \mathrm{a}$ & $17.50 \mathrm{~b}$ \\
\hline Chemical & $64.77 \mathrm{a}$ & $4.61 \mathrm{a}$ & $164.43 \mathrm{a}$ & $19.56 \mathrm{a}$ & $20.22 \mathrm{a}$ \\
\hline Organic & $67.77 \mathrm{a}$ & $4.33 \mathrm{a}$ & $132.75 \mathrm{~b}$ & $17.77 \mathrm{a}$ & $18.54 \mathrm{~b}$ \\
\hline $\begin{array}{l}1 / 2 \text { chemical } \\
+1 / 2 \text { organic }\end{array}$ & $64.89 \mathrm{a}$ & $4.27 \mathrm{a}$ & $133.67 \mathrm{~b}$ & $18.73 \mathrm{a}$ & $18.66 \mathrm{~b}$ \\
\hline
\end{tabular}

The average with same letter for each factor was no-significant according Duncan's multiple range of $5 \%$.

Table (3): Effect of interaction between varieties and fertilizers on vegetative trails of broad been.

\begin{tabular}{|c|c|c|c|c|c|c|}
\hline Varieties & Fertilizers & $\begin{array}{l}\text { Plant } \\
\text { height } \\
(\mathrm{cm})\end{array}$ & $\begin{array}{c}\text { Nu. of } \\
\text { branches } \\
\text { per plant }\end{array}$ & $\begin{array}{c}\text { Leaf area } \\
\left(\mathrm{dcm}^{2} \text {.Plant }{ }^{-1}\right)\end{array}$ & $\begin{array}{c}\text { Dry } \\
\text { matter } \\
\text { of hill } \\
\%\end{array}$ & $\begin{array}{l}\text { Pod } \\
\text { length } \\
(\mathrm{cm})\end{array}$ \\
\hline \multirow[b]{2}{*}{ French } & Control & $62.33 \mathrm{bc}$ & $4.00 \mathrm{df}$ & 162.63 & $\begin{array}{c}20.83 \\
a b\end{array}$ & $\begin{array}{c}17.33 \\
\text { bc }\end{array}$ \\
\hline & Chemical & 63.33 & $4.50 \mathrm{bc}$ & 164.97 & 20.11 & 22.33 \\
\hline
\end{tabular}




\begin{tabular}{|c|c|c|c|c|c|c|}
\hline & & $a b c$ & & & $a b$ & $\mathrm{a}$ \\
\hline & Organic & $\begin{array}{c}68.33 \\
\text { abc }\end{array}$ & $4.83 \mathrm{abc}$ & $142.57 \mathrm{bcd}$ & $\begin{array}{c}17.66 \\
\text { ab }\end{array}$ & $\begin{array}{c}18.33 \\
b c\end{array}$ \\
\hline & $\begin{array}{l}1 / 2 \text { chemical } \\
+1 / 2 \text { organic }\end{array}$ & $\begin{array}{c}67.00 \\
a b c\end{array}$ & $4.33 \mathrm{~cd}$ & $138.43 \mathrm{bcd}$ & $\begin{array}{c}21.80 \\
\mathrm{a}\end{array}$ & $\begin{array}{c}19.00 \\
\text { bc }\end{array}$ \\
\hline \multirow{4}{*}{ Turkish } & Control & $\begin{array}{c}68.00 \\
a b c\end{array}$ & $5.10 \quad \mathrm{a}$ & $114.47 \quad \mathrm{e}$ & $\begin{array}{c}15.90 \\
b\end{array}$ & $\begin{array}{c}16.83 \\
\mathrm{c}\end{array}$ \\
\hline & Chemical & $\begin{array}{c}60.00 \\
c\end{array}$ & $4.33 \mathrm{~cd}$ & $116.53 \mathrm{de}$ & $\begin{array}{c}17.47 \\
\mathrm{ab}\end{array}$ & $\begin{array}{c}19.33 \\
b c\end{array}$ \\
\hline & Organic & $\begin{array}{c}65.66 \\
a b c\end{array}$ & 3.83 ef & $112.03 \mathrm{e}$ & $\begin{array}{c}17.60 \\
\mathrm{ab}\end{array}$ & $\begin{array}{c}17.63 \\
\mathrm{bc}\end{array}$ \\
\hline & $\begin{array}{l}1 / 2 \text { chemical } \\
+1 / 2 \text { organic }\end{array}$ & $\begin{array}{c}66.00 \\
a b c\end{array}$ & $4.00 \mathrm{de}$ & $116.90 \mathrm{de}$ & $\begin{array}{c}17.02 \\
a b\end{array}$ & $\begin{array}{c}17.33 \\
b c\end{array}$ \\
\hline \multirow{4}{*}{ Local } & Control & $\begin{array}{c}66.00 \\
\text { abc }\end{array}$ & $3.50 \mathrm{f}$ & $120.07 \mathrm{cde}$ & $\begin{array}{c}19.48 \\
\text { ab }\end{array}$ & $\begin{array}{c}18.33 \\
b c\end{array}$ \\
\hline & Chemical & $71.00 \mathrm{a}$ & $5.00 \mathrm{ab}$ & 211.80 & $\begin{array}{c}21.09 \\
\mathrm{a}\end{array}$ & $\begin{array}{c}19.00 \\
b c\end{array}$ \\
\hline & Organic & $\begin{array}{l}69.33 \\
a b\end{array}$ & $4.33 \mathrm{~cd}$ & 143.67 bcd & $\begin{array}{c}18.05 \\
\mathrm{ab}\end{array}$ & $19.66 \mathrm{~b}$ \\
\hline & $\begin{array}{l}1 / 2 \text { chemical } \\
+1 / 2 \text { organic }\end{array}$ & $\begin{array}{c}66.00 \\
\mathrm{abc}\end{array}$ & $4.50 \mathrm{bc}$ & $145.70 \quad b c$ & $\begin{array}{c}17.38 \\
a b\end{array}$ & $19.67 \mathrm{~b}$ \\
\hline
\end{tabular}

The average with same letter for each factor was no-significant according Duncan's multiple range of 0.05 .

Table (4) showed that Turkish variety a significantly increased seeds weight $19.91 \mathrm{gm}$. pod $^{-1}$ compared with other varieties, while French variety a significantly increased the total yield of pods $8.45 \mathrm{t}^{\text {. ha- }}{ }^{-1}$ compared with Turkish variety only, since there is no-significant between varieties in biological yield, number of pods per plant, average of pod weight and yield of green seeds.

The results of fertilizers in table (4) chemical treatment a significantly increased the biological yield, average of pod weight, seeds weight, yield of green seeds and total yield of pods, $320.37 \mathrm{gm}, 35.26 \mathrm{gm}, 19.66 \mathrm{gm}$ pod $^{-1}, 5.48 \mathrm{t}$. ha $\mathrm{ga}^{-1}$ and $9.68 \mathrm{t}$. ha ${ }^{-1}$ respectively, while the $1 / 2$ chemical $+1 / 2$ organic treatment a significantly increased the number of pods 5.83 pod. plant $^{-1}$.

Table (5) showed that the interaction between Local variety and chemical fertilizer a significantly increased the biological yield, yield of green seeds and total yield of pods, $370.33 \mathrm{gm}, 5.91 \mathrm{t}$. ha $\mathrm{ha}^{-1}$ and $10.79 \mathrm{t}$. ha ${ }^{-1}$ respectively compared with control treatment in all varieties, while interaction between Turkish variety and $1 / 2$ chemical $+1 / 2$ organic treatment a significantly increased the number of pods and seeds weight, 6.50 pod. plant ${ }^{-1}$ and $20.40 \mathrm{gm}$ pod $^{-1}$ respectively, while the interaction between Turkish variety and control treatment a significantly increased the average of pod weight $41.66 \mathrm{gm}$. 
Table (4): Effect of varieties and different levels of organic and chemical fertilizers on yield trials of broad been.

\begin{tabular}{|c|c|c|c|c|c|c|}
\hline Varieties & $\begin{array}{c}\text { Biologica } \\
1 \text { yield } \\
\text { (gm) }\end{array}$ & $\begin{array}{l}\text { Nu. of } \\
\text { pods per } \\
\text { plant }\end{array}$ & $\begin{array}{c}\text { Average of } \\
\text { pod weight } \\
(\mathrm{gm})\end{array}$ & $\begin{array}{c}\text { Seeds } \\
\text { weight } \\
\left({\left.\mathrm{gm} . \text { pod }^{-1}\right)}^{-1}\right.\end{array}$ & $\begin{array}{c}\text { Yield of } \\
\text { green seeds } \\
\left(\text { t. ha } \text { ha }^{-1}\right)\end{array}$ & $\begin{array}{c}\text { Total yield } \\
\text { of pods } \\
\left.\text { (t.ha }^{-1}\right)\end{array}$ \\
\hline French & $284.52 \mathrm{a}$ & $5.04 \mathrm{a}$ & $30.82 \mathrm{a}$ & $18.00 \mathrm{~b}$ & $4.88 \mathrm{a}$ & $8.45 \mathrm{a}$ \\
\hline Turkish & $272.69 \mathrm{a}$ & $4.87 \mathrm{a}$ & $29.45 \mathrm{a}$ & $19.91 \mathrm{a}$ & $4.83 \mathrm{a}$ & $7.24 \mathrm{~b}$ \\
\hline Local & $303.89 \mathrm{a}$ & $5.14 \mathrm{a}$ & $31.17 \mathrm{a}$ & $18.20 \mathrm{~b}$ & $5.04 \mathrm{a}$ & $8.40 \mathrm{a}$ \\
\hline
\end{tabular}

Fertilizers:

\begin{tabular}{|c|c|c|c|c|c|c|}
\hline Control & $\begin{array}{c}243.37 \\
\mathrm{~b}\end{array}$ & $3.83 \mathrm{c}$ & $33.04 \mathrm{a}$ & $17.05 \mathrm{~b}$ & $3.45 \mathrm{~b}$ & $7.02 \mathrm{c}$ \\
\hline Chemical & $\begin{array}{c}320.37 \\
\mathrm{a}\end{array}$ & $5.18 \mathrm{~b}$ & $35.26 \mathrm{a}$ & $19.66 \mathrm{a}$ & $5.48 \mathrm{a}$ & $9.68 \mathrm{a}$ \\
\hline Organic & $\begin{array}{c}299.37 \\
\mathrm{a}\end{array}$ & $5.22 \mathrm{~b}$ & $26.90 \mathrm{~b}$ & $19.20 \mathrm{a}$ & $5.34 \mathrm{a}$ & $7.34 \mathrm{c}$ \\
\hline $\begin{array}{c}1 / 2 \\
\text { chemical } \\
+1 / 2 \\
\text { organic }\end{array}$ & $\begin{array}{c}285.03 \\
\mathrm{a}\end{array}$ & $5.83 \mathrm{a}$ & $26.71 \mathrm{~b}$ & $18.91 \mathrm{a}$ & $5.41 \mathrm{a}$ & $8.07 \mathrm{~b}$ \\
\hline
\end{tabular}

The average with same letter for each factor was no-significant according Duncan's multiple range of 0.05 .

Table (5): Effect of interaction between varieties and fertilizers on vegetative trails of broad been.

\begin{tabular}{|c|c|c|c|c|c|c|c|}
\hline Varieties & Fertilizers & $\begin{array}{c}\text { Biologica } \\
1 \text { yield } \\
(\mathrm{gm})\end{array}$ & $\begin{array}{l}\text { Nu. of } \\
\text { pods per } \\
\text { plant }\end{array}$ & $\begin{array}{l}\text { Avg. of } \\
\text { pod } \\
\text { weight } \\
(\mathrm{gm})\end{array}$ & $\begin{array}{c}\text { Seeds } \\
\text { weight } \\
\left(\mathrm{gm}^{2} \mathrm{pod}^{-1}\right)\end{array}$ & $\begin{array}{l}\text { Yield of } \\
\text { green } \\
\text { seeds } \\
\left(\mathrm{t} . \text { ha }^{-1}\right)\end{array}$ & $\begin{array}{c}\text { Total } \\
\text { yield of } \\
\text { pods } \\
\left(\mathrm{t}^{\circ} \mathrm{ha}^{-1}\right)\end{array}$ \\
\hline \multirow{4}{*}{ French } & Control & $251.33 b c$ & $4.50 \mathrm{~cd}$ & $25.72 \mathrm{def}$ & $16.66 \mathrm{c}$ & $3.99 \mathrm{bc}$ & $7.28 \mathrm{de}$ \\
\hline & Chemical & $306.89 \mathrm{ab}$ & $4.66 \mathrm{~cd}$ & $39.91 \mathrm{ab}$ & 19.33 & $4.92 \mathrm{ab}$ & $9.86 \mathrm{ab}$ \\
\hline & Organic & $279.55 b c$ & $5.83 \mathrm{ab}$ & $23.35 \mathrm{ef}$ & $18.66 \mathrm{ab}$ & $5.81 \mathrm{ab}$ & $7.25 \mathrm{de}$ \\
\hline & $\begin{array}{c}1 / 2 \\
\text { chemical } \\
+1 / 2 \\
\text { organic }\end{array}$ & $300.33 a b$ & 5.16 bc & $34.30 \mathrm{bc}$ & $17.33 \mathrm{bc}$ & $4.80 \mathrm{ab}$ & $9.42 \mathrm{~b}$ \\
\hline \multirow{4}{*}{ Turkish } & Control & $219.77 \mathrm{c}$ & 3.00 & $41.66 \mathrm{a}$ & $18.83 \mathrm{ab}$ & 3.01 & $7.02 \mathrm{de}$ \\
\hline & Chemical & $283.88 b c$ & $5.16 \mathrm{bc}$ & $30.53 \mathrm{cde}$ & 20.33 a & $5.60 \mathrm{a}$ & $8.40 \mathrm{c}$ \\
\hline & Organic & $300.22 \mathrm{ab}$ & $4.83 \mathrm{bcd}$ & 25.19def & $20.10 \mathrm{a}$ & $5.18 \mathrm{ab}$ & $6.47 \mathrm{e}$ \\
\hline & $\begin{array}{c}1 / 2 \\
\text { chemical }\end{array}$ & $286.88 b c$ & $6.50 \quad \mathrm{a}$ & $20.42 \mathrm{f}$ & $20.40 \quad \mathrm{a}$ & $5.54 \mathrm{a}$ & $7.05 \mathrm{de}$ \\
\hline
\end{tabular}




\begin{tabular}{|c|c|c|c|c|c|c|c|}
\hline & $\begin{array}{c}+1 / 2 \\
\text { organic }\end{array}$ & & & & & & \\
\hline \multirow{6}{*}{ Local } & Control & $259.00 \mathrm{bc}$ & $4.00 \mathrm{~d}$ & $31.75 \mathrm{~cd}$ & $15.67 \mathrm{c}$ & $3.34 \mathrm{c}$ & $6.47 \mathrm{e}$ \\
\cline { 2 - 9 } & Chemical & $370.33 \mathrm{a}$ & $5.73 \mathrm{ab}$ & $35.34 \mathrm{abc}$ & $19.33 \mathrm{a}$ & $5.91 \mathrm{a}$ & $10.79 \mathrm{a}$ \\
\cline { 2 - 8 } & Organic & $318.33 \mathrm{ab}$ & $5.00 \mathrm{bcd}$ & $32.16 \mathrm{~cd}$ & $18.83 \mathrm{ab}$ & $5.02 \mathrm{ab}$ & $8.30 \mathrm{c}$ \\
\cline { 2 - 8 } & $\begin{array}{c}1 / 2 \\
\text { chemical } \\
+1 / 2 \\
\text { organic }\end{array}$ & $267.89 \mathrm{bc}$ & $5.83 \mathrm{ab}$ & $25.41 \mathrm{def}$ & $19.00 \mathrm{ab}$ & $5.90 \mathrm{a}$ & $7.73 \mathrm{~cd}$ \\
\hline
\end{tabular}

The average with same letter for each factor was no-significant according Duncan's multiple range of 0.05 .

The results showed that there were significant differences between the varieties in some vegetative and yield traits, this due to differences in genotypes between varieties and differences in nature growth and extent of differences between varieties to respond to plant environment factors, many studies have confirmed that differences in vegetative and culinary characteristics are due to differences in genotypes and differences in the nature of growth between varieties (Tayel and Sabreen, 2011 Abbas ,2012 Tamene et, al.2015 Mitiku and Wolde,2015).The results showed that all fertilization factors had a positive effect on some vegetative and yield traits. The effect of the fertilization was different between the fertilization factors in the vegetative growth characteristics. The fertilization treatments also had a significant effect on most of the studied traits due to the positive effect of chemical fertilizers on most vegetative characteristics and the moral effect in most characteristics of the studied outcome tables (2-5). Plants that are fertilized with chemical fertilizer (urea) are significantly higher in vegetative growth. This may be due to the ease and readiness of the nitrogen present in the chemical fertilizer compared to the nitrogen found in the organic fertilizer that needs a long period to complete the decomposition and liberation (Cooke, 1972). Which indicated that organic fertilizers containing one third of nitrogen are easy to release and the remaining part remains unchanged for a long time in the soil. May be due to the positive role of the element of nitrogen in the chemical fertilizer, which is included in the composition of important biological substances in the plant, such as proteins, nucleic acids and chlorophyll, which helps to increase the division of cells and increase the number and thus increase vegetative growth (Yagodin,1984). Nitrogen fertilization also promotes growth by entering into the formation and construction of oxins, which have an active role in activating the division and elongation of cells as well as the entry of nitrogen in the synthesis of proteins, amino acids, nuclei and chlorophyll (Mohamed and AL-Rayes, 1982). The increase in vegetative growth characteristics by chemical fertilization (Table 2) may be due to the role of nitrogen in this fertilizer in increasing the level of natural cytokines in plant tissues that increase the total content of the glycrin oxycines and then increase and regulate the division and elongation of plant cells and inhibit the decomposition of jibrillins In increasing the components of the crop (Abu Zaid, 1990). While the positive effect 
of organic fertilizer in some vegetative growth characteristics and more yield characteristics, may be due to the organic fertilizer content of various sources on the organic compounds dissolved in water, such as sugars, amino acids and humic acids and organic acids Humvees and baldles, all these compounds contribute directly or indirectly to the growth and development of the plant are encouraging growth by enzymatic or hormonal as it contains nutrients needed by the plant or they affect the nutrient availability already present in the soil by improving soil $\mathrm{pH}$ and thus improving plant productivity (AL-Bayati and Kammel, 2014). The moral role when adding half the amount of chemical fertilizer with half the amount of organic manure in each of the number of pods, the green seeds, weight of the seeds, seeds and the biological and total yield of pods (Tables, 4 and 5), this may be due to the contribution of both mineral and organic fertilizer to each other in order to reach the state of optimal nutritional balance suitable for the growth and development of the plant because they equipped the plant with the necessary nutrients, which was reflected in significant increases in most of the indicators of the studied factor (ELShakry, 2005; Al-Habar et.al, 2014).

$$
\begin{aligned}
& \text { تأثير السماد الكيمياوي والعضوي على ثلاثة أصناف من الباقلاء } \\
& \text { وليد بدر الدين الليلة } \\
& \text { E-mail:al bayati_1956@yahoo.com }
\end{aligned}
$$

\footnotetext{
الخلاصة

نفذت الدر اسـة في حقل الخضـر اوات / قسم البستنـة وهندسـة الحدائق/ كليـة الزر اعـة و الغابـات/ جامعـة

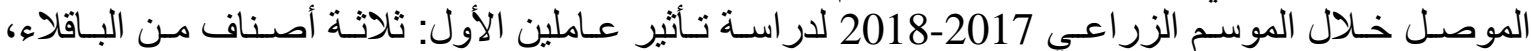

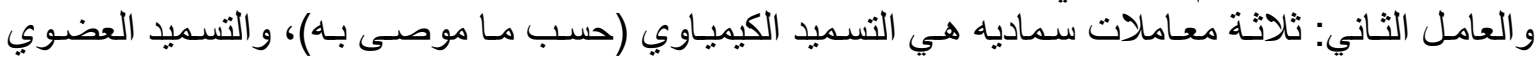

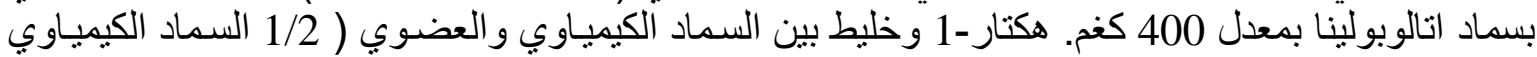

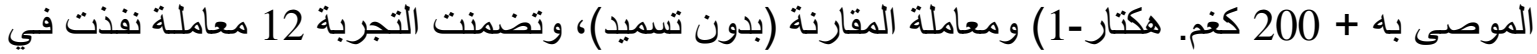

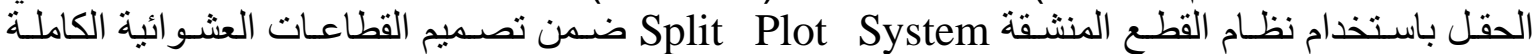

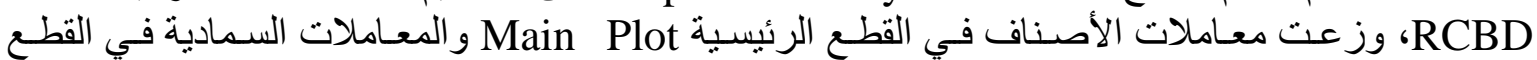

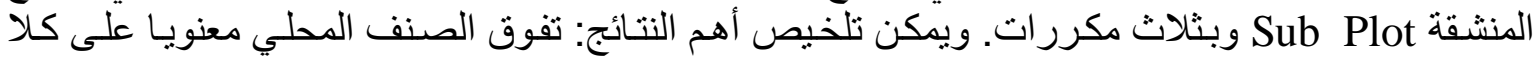

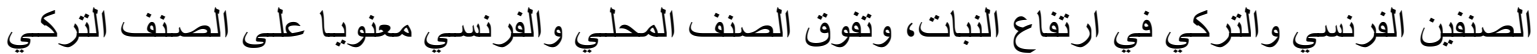

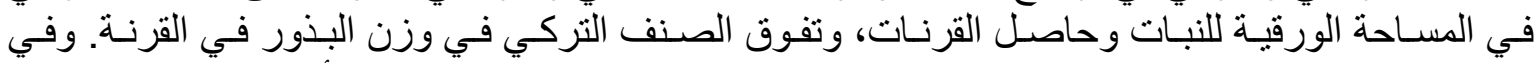

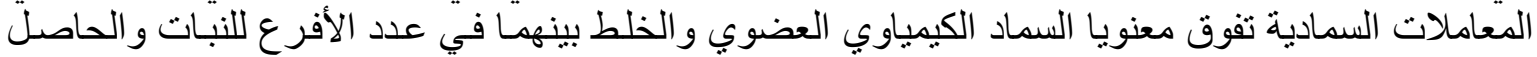

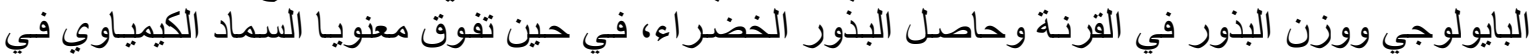

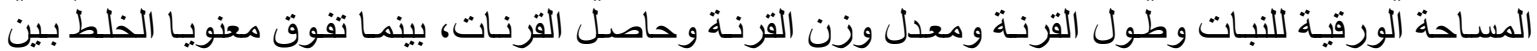

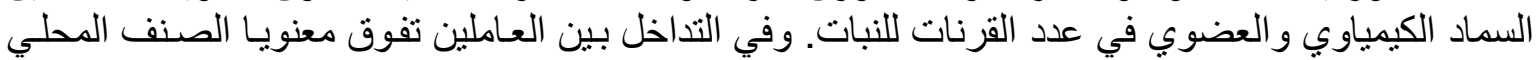

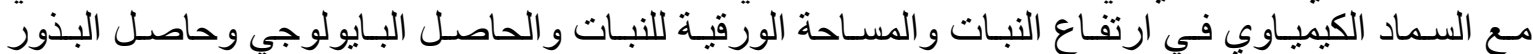

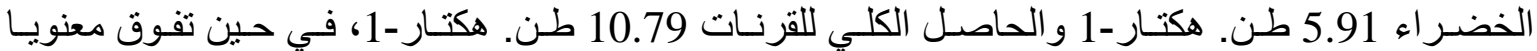

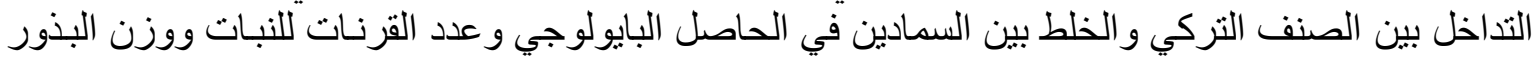

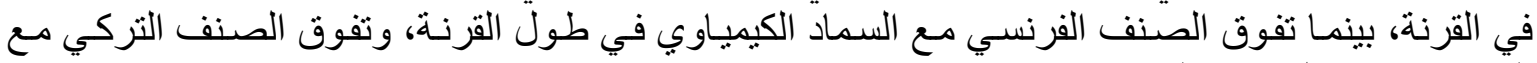

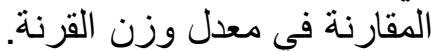

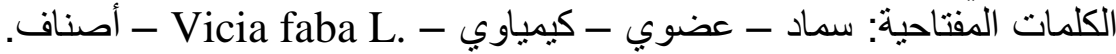
تاريخ تسلم البحث: 2019/4/24؛ وقبوله: 2019/6/30
} 


\section{REFERENCES}

Abbas, S.H. (2012). Performance analysis to genotypes characters in broad bean under effect at different levels for the fertilizer NPK. Alkufa Journal for Agricultural Science. 4(2):305-3018.

Abo-Zaid, N.S. (1990). Plant Hormones and Agricultural Application, Alder Arabia from Publishing and Distribution, Cairo. Egypt. pp 600.

AL-Bayati, H.J.M. and T.J. Kammel. (2014). Improving growth and yield by application organic fertilizers compared with chemical fertilizers on tow cucumber (Cucumis sativus L.) cultivar which grown under unheated plastic house. Mesopotamia Journal of Agriculture, 42 (1) Supple, 168- 176.

AL-Habar, M.T.; J.M. Hussein and F.R.I. Fathel. (2014). Possibility study of humic acid using as compensation or reduce of chemical fertilizer addition on potato (Solanum tuberosum L.). Mesopotamia Journal of Agriculture, 42 (1) Suppl. 68-74.

AL-Rawi, K. M. and A. M. Khalaf-Allah.(2000). Design and Analysis of Agricultural Experiments. Foundation of Dar AL-Ktob, University of Mosul, Ministry of Higher Education and Science Research, Iraq, pp. 488.

Cooke, G.W. (1972). Fertilizing For Minimum Yield. Crosby Lock Wood and Son ltd. London.

Dhary, S.I. and M.H.K. AL-Baldawi. (2017). Response of different varieties of faba bean to plant source organic fertilizers. The Iraqi Journal of Agricultural Sciences, 48 (4): 1141 - 1147.

EL-shakry, M.F.Z (2005). Humic materials for agriculture plants. Better Crops. 89 (3):1023-1025.

Farhan, L.D. 2012. The Effect of organic matter and potassium fertilizers on growth and yield of broad bean (Vicia faba L.). Diyala Journal of Agriculture Sciences, 4 (1): $50-61$.

Ibrahem, R.H. (2011). Response of two faba bean cultivars to foliar application. The Kufa Journal of Agriculture Sciences, 3 (2): 85 - 92.

Jasem, A.H.; H.A. Atab and H.M. Abed. (2015). Effect of organic and chemical fertilizers and their interaction with foliar fertilizers on yield of broad bean ( Vicia faba L.). Euphrates Journal of Agriculture Sciences, 7 (4): 44- 48.

Jassim, A.H. and AL-Dulaimi. (2012). Effect of adding organic fertilizers and foliar application of humic acid and seaweed extract in growth and green pod yield of broad bean (Vicia faba L.). Euphrates Journal of Agriculture Sciences, 6 (1): 163-172.

Kakahy, A.N.; N.D. Ahmad and A.S. Abdullahi. (2012). The effect of planting distance on yield of bean (Vicia faba L.) under drip irrigation system. African Journal of Agricultural Research, 46 (7): 6110 - 6114.

Kamal, J.A.; G.B.A. AL-Abbasi and F.S. Salman. (2016). Effect of organic fertilizer and urea application on growth and yield of faba bean (Vicia faba L.). University of Babylon Journal Application Sciences, 24 (4): 991 1002. 
Kandil, S.A. and Z.R. Hala. (2007). Effect of cobalt fertilizers on growth, yield and nutrient of faba bean (Vicia faba L.). Plant Journal of Applied Sciences Research, 3 (9): $867-872$.

Kandil, S.A. and W. Erskine . (2007). Combat ion disease problem of grain broiler diets. Effect of extrusion on growth performance, Italian Anim. Science, 5: $43-53$.

Mitiku, A.B. and M. Wolde (2015). Effect of faba bean ( Vicia faba L.) varieties on yield attributes at sinana and agarfa districts of bale zone. Southeastern Ethiopia Jordan Journal of Biological Sciences. 8(4): 281-286.

Mohammed, A.A.K. and A.H. AL-Rayes. (1982). Plant Physiology. $2^{\text {ed }}$, Dar ALKutub Printing and Publishing, University of Mosul, Iraq.

Nuaimi, S.A.N. (2011). Principles of Plant Nutrition. (Translated). $5^{\text {th }}$ Edition. Ministry of Higher Education and Science Research, Iraq. 1440 pp.

Ramadan, M.A.E. and S.M. Adam. (2007). The effect of chicken manure and mineral fertilizers on distribution of heavy metals in soil and tomato organs. Australia Journal of Basic ana Applied Sciences, 1 (3): 226 - 231.

Sabh, A.Z. and M.A. Shallan. (2008). Effect of organic fertilization on broad bean (Vicia faba L.) by using different merino macro-algae in relation to morphological characteristics and chemical constituents of the plant. Australian Journal of Basic and Application Sciences, 2 (4): 107 - 109.

Anonymous (2001). SAS users guide, Personal computers Inst. Inc. Cary. N. C. USA.

Sharma, A.K. (2002). Bio-Fertilizers Sustainable Agriculture. Agro bios Indian Publication, $407 \mathrm{pp}$.

Tamene, T; K. Gemchu and A. Hussein .(2015). Genetic progresses from over three decades of faba bean(Vicia faba L.) breeding in Ethiopia. Australia Journal Agriculture of Crop Science. 5:110-117.

Tayel, M.Y and K.H.P. Sabreen. (2011). Effect of irrigation regimes and phosphorus levels on tow Vicia faba varieties growth characters. Journal of Applied Science. 7(6): 1007-1015.

Tsvetkova, G.E. and G.I. Georgiev. (2007). Changes in phosphate fractions extracted from different organs of phosphorus starved nitrogen fixing pea plants. Journal of Plant Nutrition, 30, 2129 - 2140. Hemistry (Led).Mir Publishers. Moscow. Ussr.

Yagodin, B.A.(1984). Agriculture Chemistry (1 $\left.{ }^{\mathrm{ed}}\right)$. Mir Publishers, Moscow. USSR. 